\title{
APPROACH TO STUDENTS' SOCIAL REPRESENTATIONS IN THE CONSTRUCTION OF ACADEMIC EUROPEAN GEOGRAPHY: A CASE STUDY OF SPANISH UNIVERSITY STUDENTS ${ }^{1}$
}

\author{
Xosé Carlos Macía Arce ${ }^{1}$, Rubén Camilo lois GonZález², \\ Francisco Rodríguez Lestegás ${ }^{3}$, Francisco Xosé Armas Quintá ${ }^{3}$
}

${ }^{1}$ Department of Applied Didactics, Faculty of Education Sciences, University of Santiago de Compostela, Spain ${ }^{2}$ Department of Geography, Faculty of Geography and History, University of Santiago de Compostela, Spain ${ }^{3}$ Department of Applied Didactics, Faculty of Teacher Training, University of Santiago de Compostela, Spain

Manuscript received: January 30, 2017

Revised version: November 10, 2017

\begin{abstract}
Macía-Arce X.C., Lois-GonzÁlez R.C., Rodríguez-Lestegás F., Armas-Quintá F.X., Approach to students' social representations in the construction of academic European geography: A case study of Spanish university students. Quaestiones Geographicae 36(4), Bogucki Wydawnictwo Naukowe, Poznań, pp. 159-170, 5 tables, 4 figs.

ABSTRACT: This article provides the results of classroom research involving university students training to be secondary school teachers of geography and history. The research is based on the analysis of a word association test on Europe and the European Union. The results constitute an approach to the geographical and historical representations these students have of their own European continent. This is a fundamental question considering that this collective group is training to teach the contents and values of European geography in secondary school education. From here on, our intention is no other than to carry out an exercise of synthesis and overall reflection on the test results and introduce issues which could generate some debate in the educational community.
\end{abstract}

KEYWORDS: academic geography of Europe, teacher training for secondary education, social representations, test of word association.

Corresponding author: Xosé Carlos Macía Arce, Department of Applied Didactics, Faculty of Education Sciences, University of Santiago de Compostela, Spain, Arda. Xoán XXIII, s/n. Campus Norte, 15782 Santiago de Compostela, Spain,

e-mail:carlos.macia@usc.es

This publication was prepared under the framework of a project called Social skills for a democratic citizenship: analysis, development and assessment [EDU2015-65621-C3-1-R], funded by the State Programme for Research, Development and Innovation Focusing on Challenges in Society for the Government of Spain [R+D+I, call 2015], the network of excellence - Red14 (State Plan for Scientific and Technical Research and Innovation 2013-2016, EDU2014-51720REDT) and NEDAT (Programme for the Consolidation and Structuring of Competitive Research in the Galician University System, Network mode, R2014/018). 


\section{Introduction}

The Galician secondary education curriculum ${ }^{2}$ (Spain) concerning Europe and the European Union refers to physical and human geography of the old continent. It is merely descriptive and maintains, on many occasions, geographical attitudes which are of little or no relevance to students (Novales, Macía 2017; Rodriguez, Macía, Rodriguez 2017). The traditional content affects interest in a school subject that has clearly been surpassed by a constantly changing society. Beyond the initial rote learning of geographical features or population densities, we believe that there is more to geography. There is a geography that can provide a more enquiry-based learning and critically reflect on the social, economic and political realities that are part of our local, national and European environment (Macía, Rodriguez, Armas 2015). Therefore, fundamental questions for the present and future for all European citizens, like the processes of growing inequality and poverty across regions, migration, political decisions on long-standing nationalisms, territorial tensions and the gradual disappearance of the welfare state are issues that continue to be realities and need strong curricular reinforcement.

Moreover, we have many doubts over the geographic concepts of students in teacher training for secondary education. Hence, this article will provide the results of classroom research with university students using a word association test about Europe and the European Union. The results represent an initial approach to the geographical and historical representations these students have of their own continent. This is an important issue considering that this group of students will join teaching staff tasked with explaining European geography in secondary school education. It seems to be quite clear that a teacher's initial selection of geographical content will lead to the smooth running of the classes and, consequently, will affect their students' knowledge and their present and future attitudes towards being European citizens.

Galicia is a Spanish region located in the northwest of the Iberian Peninsula. It is not to be confused with Galitzia or Galicja, other European regions in Poland (the voivodships of Malopolskie and Podkarpackie) and the Ukraine (the oblasts of Lviv, Ternopil, Zakarpattia and Ivano-Frankivsk).
The research was carried out with a specific group from the Galician University community. A small sample was chosen as there was never any intention of extrapolating or generalising data or conclusions. Furthermore, there are statistical data from the test results which can only provide a toehold prior to the qualitative analysis we are truly interested in. Quantitative research was never an option for this article as the sample is very small and the results lack the minimum rigour required for research. From here on, the objective was no other than to carry out an exercise of qualitative synthesis on the test results, and to introduce specific issues which could generate certain debate within the educational community.

\section{Methodology and justification}

It was decided to use a word association test to carry out this research. The test involved relating a maximum of ten words to a word that acted as a prompt (Macía, Armas 2015; Bale 2014; Bruno, Barreiro, Kriger 2011; Denegri et al. 2010; Liu et al. 2005; Gil Saura 1994; Storm 1984). In this test participants assigned a score to each of the related words (hereinafter referred to as associated words), ten points had to be awarded to the word they identified most with a prompt word, nine to the second and so on until only one point

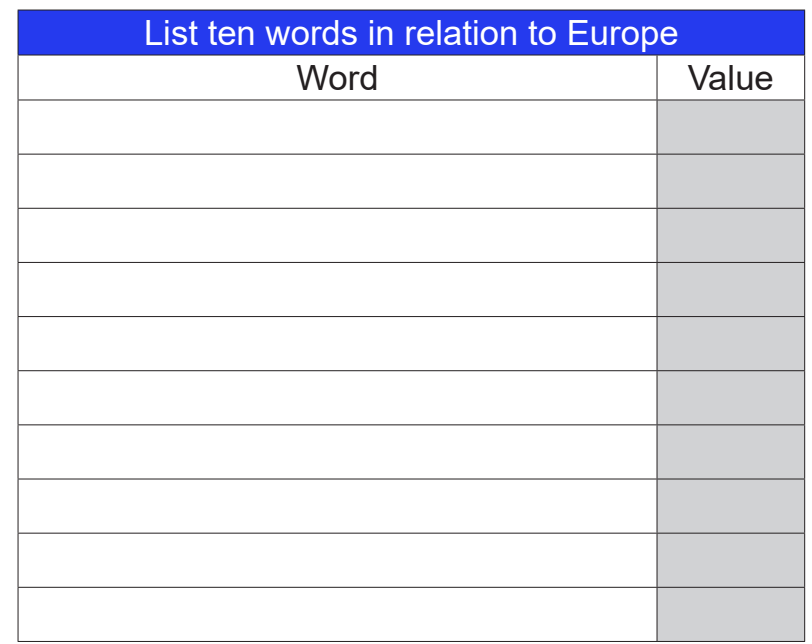

Give a value from 10 to 1 depending on its relevance to Europe, where 10 is most relevant and 1 least relevant.

Fig. 1. An associated word test proposed for students in training to be secondary school teachers.

Source: associated word pre-test on Europe, University of Santiago de Compostela, 2015. 


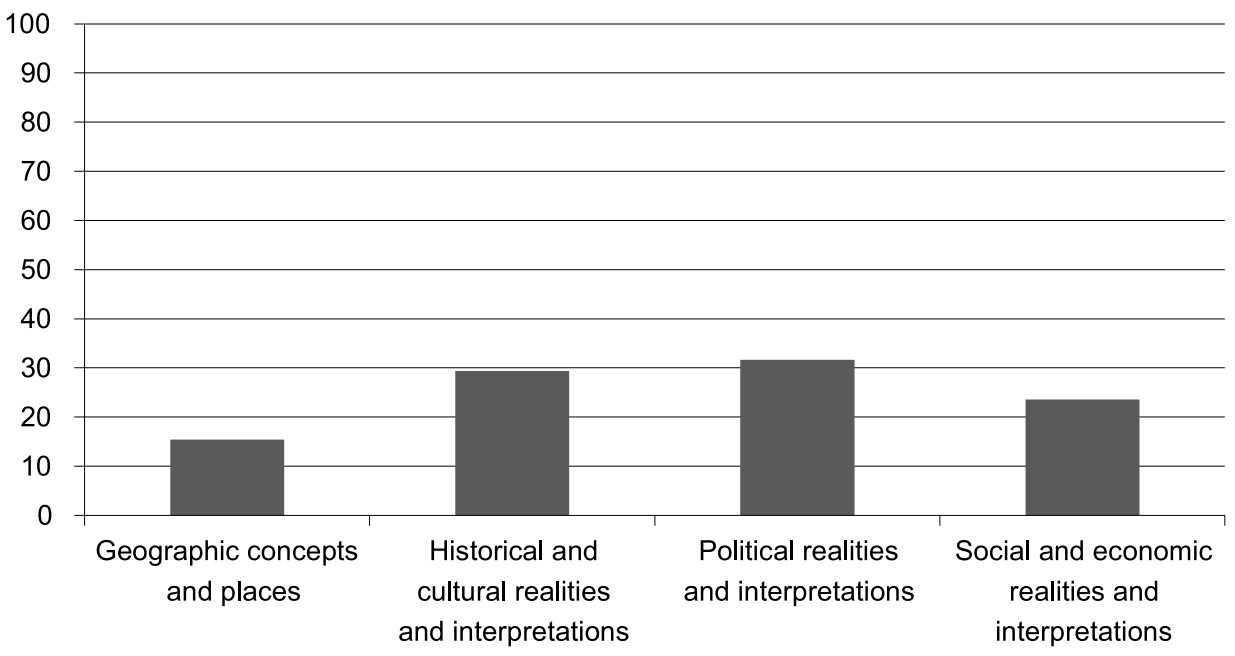

Fig. 2. Percentage distribution in semantic fields of the words shaping the concept of Europe after an associated word test on students in training to be teachers in secondary education.

Source: associated word pre-test on Europe, University of Santiago de Compostela, 2015.

would be given to the word that they identified least with a prompt word.

We were particularly interested in working on the initial concepts of Europe and the European Union held by the university students in training to be geography and history teachers in secondary education. Therefore, it was decided that the word Europe would be selected as an introductory prompt word in our associated word test, especially as this word required that the test participants produce ten words related to it (see Fig. 1). Thus, in January 2015, tests were given to 23 Master's Degree students in Teacher Training for Compulsory Secondary Education and Sixth Form Studies, Vocational Training and Language Teaching at the University of Santiago de Compostela (approximately more than half of the students enrolled in this specific module in social sciences). The result was 221 associated words and an accumulated value of 1,206 points after summing up the hierarchical scores.

In accordance with the conceptual approach of associated words, the next step in the methodology was to group the words into four semantic fields (see Fig. 2 and Table 1) and 34 categories (see Tables 2 to 5):

1. Words associated with geographic concepts and places ${ }^{3}$ :

3 The wide range of words obtained from the test led to the creation of categories within each of the four semantic fields. Thus, for example, within the semantic field related to geographical concepts and places the following words are grouped: Brussels, Strasbourg,
- cities and geographic regions,

- continent,

- territory and border,

- geographic location,

- nature.

2. Words associated with political realities and interpretations:

- European Union,

- treaties and European institutions,

- adequate political order,

- democracy,

- government and political leaders,

- eurocentrism,

- forms of government,

- politics,

- corruption,

- armed conflicts,

- political crisis,

- nationalisms,

- international political organisations.

3. Words associated with social and economic realities and interpretations:

- capitalism and globalisation,

- monetary union,

Paris, Rome, Germany, the Atlantic Ocean and the Mediterranean Sea in the category of cities and geographical regions. On the other hand, in the continent category the words are grouped with reference to Europe as a continental structure. In the territory and border category these words are border and barriers. In the geographical location category the words are map and western. Lastly, in the nature category only the word nature is included. 
Table 1. Semantic fields shaping the concept of Europe after a word association test on students in training to be teachers in secondary education.

\begin{tabular}{|c|c|c|c|c|}
\hline Semantic fields & P1 & P2 & V1 & $\mathrm{V} 2$ \\
\hline Words associated with geographic concepts and places & 34 & 15.39 & 156 & 12.94 \\
\hline Words associated with political realities and interpretations & 65 & 29.41 & 419 & 34.74 \\
\hline $\begin{array}{l}\text { Words associated with social and economic realities and } \\
\text { interpretations }\end{array}$ & 70 & 31.67 & 347 & 28.77 \\
\hline $\begin{array}{l}\text { Words associated with historical and cultural realities and } \\
\text { interpretations }\end{array}$ & 52 & 23.53 & 284 & 23.55 \\
\hline Total values & 221 & 100 & 1206 & 100 \\
\hline
\end{tabular}

Methodological note: P1 and P2 variables indicate, respectively, the number of words associated with each semantic field and its percentage value on the total number of words contained in the test. However, V1 and V2 variables indicate, respectively, the sum of the accumulated value of the words associated with each semantic field and the percentage value of the total number of words gathered in the test.

Source: associated word pre-test on Europe. University of Santiago de Compostela, 2015.

- unemployment and inequality,

- development,

- economic crisis,

- economic union,

- economic organisations,

- citizenship and social commitment.

4. Words associated with historical and cultural realities and interpretations:

- history,

- cultural diversity,

- identity and heritage,

- culture,

- religion,

- education,

- art,

- music and sports.

Finally, the frequency of repetition of each of the associated words was measured and the sum of the accumulated value was calculated (see Table 1). It should be made clear that on many occasions the words grouped in the same category are not exactly the same, but they do, at least, have a very close meaning or relationship. For example, the terms quality education, education, Erasmus, PISA and PISA tests were grouped into the semantic field of "Words associated with historical and cultural realities and interpretations" and under a single category called "Education".

Naturally, the results from such a small sample cannot be considered conclusive. Indeed, they are not intended to represent every university student's understanding of the geographical, political, social, economic, historical and cultural realities and interpretations of Europe. In short, this article points out to the content of each semantic field shaping the concept of Europe. The intention is to highlight the lack of certain aspects in curriculum in the initial steps through an experiment with university students training to be geography and history teachers in secondary education. To enable the interpretation of the test results, four tables containing the categories

Table 2. Categories shaping the semantic field on geographic concepts and places after an associated word test on students in training to be teachers in secondary education.

\begin{tabular}{|l|r|r|r|r|r|r|}
\hline \multicolumn{1}{|c|}{ Associated words } & P1 & P2 & P3 & V1 & V2 & V3 \\
\hline Cities and geographic regions & 16 & 47.06 & 7.24 & 60 & 38.46 & 4.98 \\
\hline Continent & 8 & 23.53 & 3.62 & 49 & 31.41 & 4.06 \\
\hline Territory and border & 5 & 14.71 & 2.26 & 19 & 12.18 & 1.58 \\
\hline Geographic location & 4 & 11.76 & 1.81 & 22 & 14.10 & 1.82 \\
\hline Nature & 1 & 2.94 & 0.45 & 6 & 3.85 & 0.50 \\
\hline Total values & 34 & 100 & 15.38 & 156 & 100 & 12.94 \\
\hline
\end{tabular}

Methodological note for tables 2 to 5: P1, P2 and P3 variables indicate the number of words associated with each category (P1) and their percentage value within the semantic field (P2) and the total number of words contained in the test (P3). While, V1, V2, and V3 variables indicate the sum of the accumulated value of words associated with each category (V1) and their percentage value within the semantic field (V2) and the total number of words contained in the test (V3).

Source: associated word pre-test on Europe, University of Santiago de Compostela, 2015. 
within each of the semantic fields are included. The tables show the number of repeated words in each category and the accumulated value of the semantic fields and the total number of words (see Tables 2 to 5). Nevertheless, this analysis is neither intended to be a mere repetition of numbers and percentages, a role which can be clearly noted by the tables presented in the following four sections, nor does it intend to announce every word shaping each category on approaches to Europe. We are convinced that it would be a very simple and descriptive exercise which would not lead us to any definite conclusions. In short, given that the sample size is so small, this article does not seek to focus the research on simple statistical analysis.

On the contrary, the intention of this article is no other than to provide an exercise of synthesis and qualitative reflection on the test results by introducing specific issues that can generate discussion in the educational community. The sole intention is to "bring to the table" some of the curricular content that goes unnoticed in social sciences at university level. In this respect, it should again be reiterated that the students who participated in the test specialised in geography, history, history of art, sociology, and economics. As stated in the introduction, these are students with notable intellectual backgrounds and a desire to work as secondary school teachers. That is why we consider the strategic value of our test as a research tool in the didactic field of geography.

\section{Semantic field associated with concepts and geographic locations}

Firstly, it is interesting to analyse the students' spatial awareness in respect to the peripheral location of Galicia in Atlantic Europe. It is a vast area that includes all the lands shaped and influenced by the Atlantic Ocean, from Tromso (Norway) to Punta Tarifa (Spain) (O'Flanagan 2001). It is then hardly surprising that this geographical reality is present in the contents of the Galician curriculum for secondary education ${ }^{4}$ (Decree 86/2015; Decree 133/2007).

4 The Autonomic Statute of Galicia, in Article 31, establishes that the Autonomic Community has complete control over the regulation and administration of

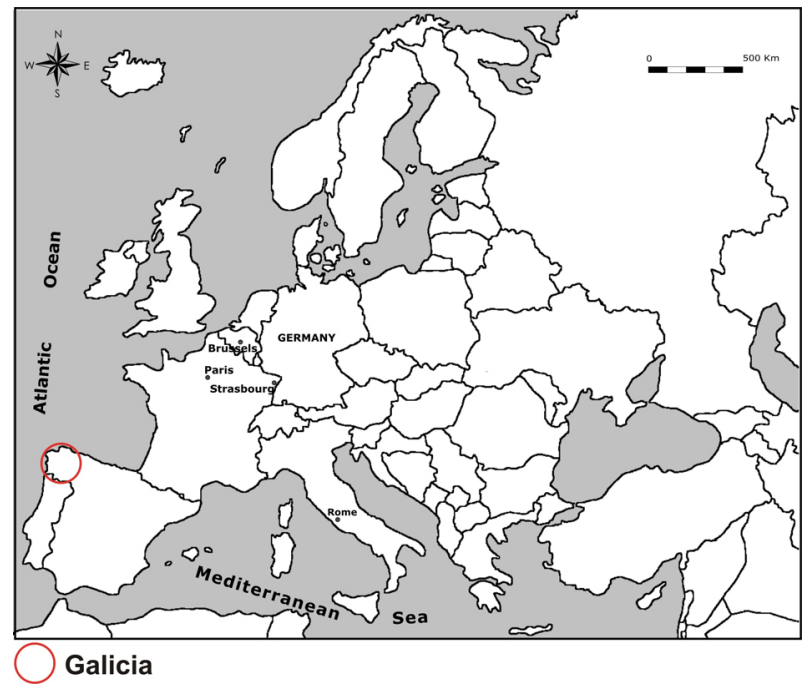

Fig. 3. Political map of Europe showing the imaginary spaces after the associated word test on students in training to be teachers in secondary education. Source: pre-associated word test on Europe, University of Santiago de Compostela, 2015.

It is rather curious to note that the test results reveal only one reference to the Atlantic Ocean, yet four mentions of the Mediterranean Sea (see Fig. 3). This gives the impression that, for these students, Europe is more inclined towards the Mediterranean culture, which seems an exceptional fact given the normal daily life of Galician people: fishing, overseas migration, the role of the Atlantic ports and so on. In addition, Galicia's rainy climate, green landscape, smallholder agriculture and dispersed rural communities are examples shaping the identity of people that have little or nothing to do with the realities in the Mediterranean (Macía 2007; Ferrás 1996).

The students' perceptions are undoubtedly connected to their previous education and school textbooks which attach great importance to the Mediterranean culture in Europe. Moreover, there is a propaganda machine that strengthened Spain as a "sun and beach" tourist destination (Santos 2015), using a Mediterranean image far removed from any Galician reality (Lois, Piñeira, Santomil 2009). Henceforth, we question the value of educational systems which embrace the teaching of geographic content without any regard to local realities. This is not to say that

education in all its facets, levels and grades, modalities and specialties, without interfering with that set down in Article 27 of the Spanish Constitution and in the organic laws. 
importance should not be given to the presence of the Mediterranean Sea when students think of Europe, but it is very difficult to understand why a group of Galician university students, with specific education in geography and history, choose to omit the Atlantic Ocean from social representations, just like we would not expect it from Polish university students living next to the Baltic Sea.

Secondly, students do not take into account the existence of European spaces outside the European Union. The only cities cited in the test are Brussels (on 4 occasions), Strasbourg, Paris and Rome. The first two are identified within the European Union's administrative region, with an imaginary axis that connects the cities of Brussels, Luxembourg and Strasbourg. On the other hand, Paris and Rome represent two main metropolitan areas (Eurostat, Urban Audit 2015). Away from the cities, only Germany is cited as a country, probably for its role in the current social and economic adjustment policies. Therefore, we can see that the imagined territories are always related to the European Union and areas of power (see Fig. 3) 5 .

The population's mental picture of the territory might explain many structures, processes and man's behaviour on Earth. The transposition of these images into a specific city and regional maps at a local and global scale are very interesting. Peter Gould, British, was an enthusiastic promoter of this geographical exercise in the 1960s and 1970s. For example, in one of his studies he mapped out the students' residential preferences, on a national level, at four North-American universities (Gould 1972). A researcher by the name of Elliott (1979) provided another significant experience when he analysed texts of historical characters in order to map out their way of understanding and valuing the various territories in the world. To carry out this research he classified these characters' rationale into five opinion categories: territories or regions receiving the highest praise, the highest criticism, praised, criticised and ambiguous or indifferent.

Mind maps are a good tool to acquire important geographical knowledge (Buzai 2011). However, our article does not deal with this type of learning resources. We basically limit ourselves to mapping cities, regions and geographic features mentioned in the test results, with the only objective to visualise spaces that are part of our students' thinking. In other words, the intention is no more than merely representative. Nevertheless, mind maps based on preferences to appreciate the environment are a very good opportunity for learning (Gould and White 1986). It would undoubtedly be a highly suitable exercise for students in following tests.
In society today, European citizens can have the feeling of being in constant touch with the political and financial life that is going on at the "heart of Europe". This is a preferred location for factual power, especially for media and their media-related allies and, as such, all other realities outside this glorified space lose communicative strength and enjoy less interest. The immediate consequence is the mere presence of peripheral locations, including those of the European Union, and spaces which, in our test, all fall outside our students' spatial representations.

In reality, the students do not make any reference to any Eastern European countries, not even as an example of one of the great European macro-regions. Likewise, it is surprising that cities like Belgrade, Bratislava, Bucharest, Budapest, Krakow, Prague or Warsaw go unnoticed by a group of students in geography and history teacher training. At this point, many questions come to mind: is something similar happening with the training received by students in other parts of Europe? Are students in North Rhine Westphalia establishing their spatial awareness only and exclusively in central Europe? Are the students of Pomerania, Silesia and Wallachia distancing themselves from Mediterranean Europe? If so, how do we intend to build a "strong European identity"? By disregarding diversity? Not only is it spatially but also cognitively distant by the implementation of learning systems anchored in localism and the immediate environment. In our opinion, local geography is extremely important as it represents an ideal starting point to teach geography from a global perspective, while always considering geographic realities in a particular region. Focusing on specific geography, while omitting the rest, is a didactic error which must be avoided.

The decree $86 / 2015$ of June 25th, which establishes the compulsory curriculum of secondary and sixth form education in the Autonomic Community of Galicia, proposes a descriptive geography supported by quantitative methodologies (the same curriculum recognises mathematical competence as one of the most prominent

The idea would be to select European countries by preference in a ranking where $\mathrm{X} 1$ would be the most favoured country, $\mathrm{X} 2$ the second and so on until XZ, which would be the least desirable country. 
in geographical education. Also, among the curricular materials, it gives preference to applied mathematics in social sciences) and focuses almost exclusively on the territorial bonds within Spain. In fact, in the second year of sixth form education (in Spain and Galicia this is the last year of study before going to university) the curriculum provides a content of 12 units, of which 11 are devoted to the physical, human and economic geography of Spain. Only one unit covers Spain in Europe and the world, clarifying that contents related to the "close geographical areas and other areas of the world whose political, social and economic aspects keep links with Spain" will be of interest. (Decree 86/2015: 25,434).

Beyond this local and tremendously economistic geography, we understand there can be a "fresh, integrated global geography", which is consistent with social and economic realities of not only the European Union but also of the rest of the European continent and the world. A clear commitment to social geography which would be based on quantitative methodologies and especially qualitative ones. In short, a broad and descriptive school geography, but also active, reflective and critical (Macía et al. 2015).

We are convinced of the usefulness of this "new school geography" but we are aware that there are also difficulties connected with experimentation in classrooms. For example, in the 2013-14 academic year, a teaching unit on European development and territorial cohesion for university students in training to be primary school teachers was set up. This unit's methodology was teamwork and students themselves were responsible for seeking, analysing and presenting information on different socioeconomic realities on the European continent. The course ended with the completion of an associated word test on Europe to check on the students' new spatial concepts, but the results were unexpected. Except for the Vatican City, the imagined spaces focused on the European Union, especially on the central territories. Scandinavian countries, the Baltic Sea region, the Balkans and the Black Sea did not have any representation in the students' mind map. In Eastern Europe, only the Carpathian region was mentioned, an alpine mountain range that runs mainly through Romania, Austria, the Czech Republic, Slovakia, Poland, the Ukraine, Serbia and Hungary (see Fig. 4).

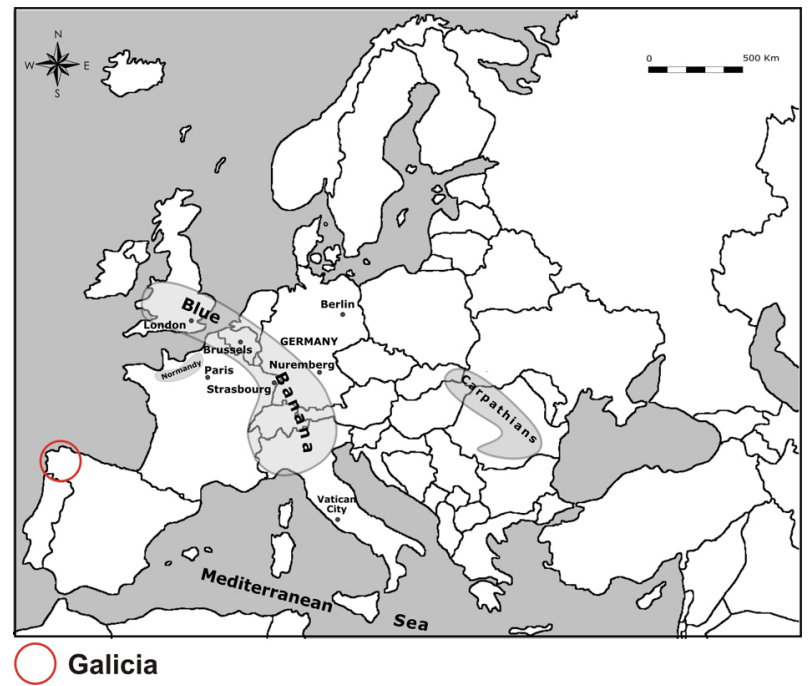

Fig. 4. Political map of Europe showing imaginary spaces after the application of an associated word test on students in training to be primary school teachers. Source: associated word post-test on Europe, University of Santiago de Compostela, 2014.

The first international conferences on landscape protection (Bern 1913), and natural monuments (Paris 1923), the creation of the International Union for the Conservation of Nature (1948), the development of strategic reports on preservation (United Nations 1987) and the holding of large Earth Summits (Stockholm 1972; Rio de Janeiro 1992: Johannesburg 2002 and Rio+20 2012) raised the public's awareness of the environment and sustainable development. In the case of Europe, this awareness meant the promotion of protected natural spaces throughout the continent in the form of legislative laws that led to national parks, natural parks, biosphere reserves and other smaller initiatives within the Natura 2000 Network.

However, if the test results are analysed, environmental protection goes largely unnoticed by students. Nevertheless, there are more references to words such as urbanism or cities, which highlight the students' European notion of urban landscapes. This situation should not come as a surprise given that three quarters of the European population reside in cities and urban areas (Eurostat 2015).

\section{Words associated with political, social, economic, historical and cultural realities and interpretations}

The European Union (on 15 occasions) is the second most repeated reference in the test (see Table 
3). Without a doubt, students' social representations identify the European Union and its institutions (Presidency, Parliament and European Central Bank) as the most significant part in a mind map of the European continent. However, an appropriate secondary education curriculum cannot just focus on the European Union. It should also highlight such countries as Russia, Ukraine, Belarus, Switzerland or Norway. Indeed, there is evidence to suggest that some of students' interpretations of Europe are biased, and it would be worthwhile to discover why this is the case. It is vital that any social construction would not become reality just for the fact of being universally shared (Liu 2005).

As a matter of fact, corruption (2 words) and the political crisis (2) are hardly mentioned in the prompted responses. In the present context, it seems to be, at the very least, surprising. Corruption cases are notorious in Spain (ERE case, the Noos case, Operation Pokemon, the Gürtel Plot, the Punica Operation or the 3\% commissions in Catalonia are just a few examples of political corruption in Spain). They occur not only in Spain but also in Europe, where Nicolas Sarkozy was charged with the illegal use of influences, Berlusconi was removed from politics for corruption and José Socrates was imprisoned for money laundering and tax fraud. Conversely, there are many more words related to democracy (7) and sound political order (7) (see Table 3). In essence, corruption cases, politicians brought to justice and capital flight do not seem to occupy learners' minds. One may wonder what kind of education students receive in the field of social sciences. Are they provided with reflective and critical education, or only with rote learning of data and content? (Macía et al. 2015). Today, innovation in the classroom is more necessary than ever in order to break away from purely descriptive processes. The European experience of the social, economic and political crisis of recent years "tells us that change is only possible with independent criteria. This is possible to develop with, and through, educational innovation" (Souto 2013: 3).

In addition, the little importance attached to nationalism in students' social representations seems somewhat surprising. Struggles for independence in Scotland and Catalonia have been featured in both national and international news of the mainstream media for months, but there is only one reference to the word nationalism (see Table 3). In general, and to a greater or lesser extent, there are many nationalist aspirations in Europe (Galicia, the Basque Country, Catalonia, Brittany, Corsica, Veneto, Lombardy, Flanders, Scotland, Wales, Northern Ireland and so on) and many territorial tensions or open borders (Crimea, Donetsk and Lugansk in Ukraine; Bukovina, Moldavia and Cobasna in Rumania; Kosovo and Vojvodina in Serbia; the Turkish Republic of Northern Cyprus etc). In other words, nationalist realities in Europe are very noticeable and should not be excluded from students' spatial representations. For us, the European identity cannot be exclusively limited to global

Table 3. Categories shaping the semantic field on political realities and interpretations after an associated word test on students in training to be secondary education teachers.

\begin{tabular}{|c|c|c|c|c|c|c|}
\hline Associated words & P1 & P2 & P3 & V1 & $\mathrm{V} 2$ & V3 \\
\hline European Union & 15 & 23.08 & 6.79 & 102 & 24.34 & 8.46 \\
\hline European treaties and institutions & 8 & 12.31 & 3.62 & 51 & 12.17 & 4.23 \\
\hline Adequate political order & 7 & 10.77 & 3.17 & 56 & 13.37 & 4.64 \\
\hline Democracy & 7 & 10.77 & 3.17 & 55 & 13.13 & 4.56 \\
\hline Government and political leaders & 6 & 9.23 & 2.71 & 28 & 6.68 & 2.32 \\
\hline Eurocentrism & 5 & 7.69 & 2.26 & 35 & 8.35 & 2.90 \\
\hline Forms of government & 5 & 7.69 & 2.26 & 27 & 6.44 & 2.24 \\
\hline Politics & 4 & 6.15 & 1.81 & 19 & 4.53 & 1.58 \\
\hline Corruption & 2 & 3.08 & 0.90 & 15 & 3.58 & 1.24 \\
\hline Armed conflicts & 2 & 3.08 & 0.90 & 14 & 3.34 & 1.16 \\
\hline Political crisis & 2 & 3.08 & 0.90 & 3 & 0.72 & 0.25 \\
\hline Nationalisms & 1 & 1.54 & 0.45 & 7 & 1.67 & 0.58 \\
\hline International political organisations & 1 & 1.54 & 0.45 & 7 & 1.67 & 0.58 \\
\hline Total values & 65 & 100 & 29.41 & 419 & 100 & 34.74 \\
\hline
\end{tabular}

Source: associated word pre-test on Europe, University of Santiago de Compostela, 2015. 
Table 4. Categories shaping the semantic field on social and economic realities and social interpretations after the associated word test on students in training to be teachers in secondary education.

\begin{tabular}{|c|c|c|c|c|c|c|}
\hline Associated words & P1 & P2 & P3 & V1 & $\mathrm{V} 2$ & V3 \\
\hline Capitalism and globalisation & 29 & 41.43 & 13.12 & 138 & 39.77 & 11.44 \\
\hline Monetary union & 16 & 22.86 & 7.24 & 62 & 17.87 & 5.14 \\
\hline Unemployment and inequality & 8 & 11.43 & 3.62 & 47 & 13.54 & 3.90 \\
\hline Development & 5 & 7.14 & 2.26 & 33 & 9.51 & 2.74 \\
\hline Economic crisis & 4 & 5.71 & 1.81 & 22 & 6.34 & 1.82 \\
\hline Economic union & 3 & 4.29 & 1.36 & 20 & 5.76 & 1.66 \\
\hline Economic organisations & 3 & 4.29 & 1.36 & 10 & 2.88 & 0.83 \\
\hline Citizenship and social commitment & 2 & 2.86 & 0.90 & 15 & 4.32 & 1.24 \\
\hline Total values & 70 & 100 & 31.67 & 347 & 100 & 28.77 \\
\hline
\end{tabular}

Source: associated word pre-test on Europe, University of Santiago de Compostela, 2015.

knowledge, it is also necessary to teach, understand and integrate unique places and their interactions with other spaces (Rodríguez Lestegás 2009). However, it seems, with hardly any exceptions, that most countries only look inwardly. In Spain, for example, no agreement can be found in secondary school textbooks on whether Transcaucasian countries (Armenia, Azerbaijan and Georgia) are inside or outside Europe (Prats et al 2001). The introduction of the basic concepts of political geography in Europe with error or confusion means that different continental realities are more difficult to explain and understand.

Furthermore, territorial realities in border areas do not seem to be very interesting, which should not come as a surprise if we examine some of the contents suggested in some school textbooks in Europe. For example, Claudino (2010) reports the absence of Portuguese geography and history in Spanish secondary school textbooks. The author regrets there is no closer curricular relationship between Spain and Portugal, and complains that there is still some 19th century nationalist tone in the textbooks. Ultimately, he recognises that geography in Portugal is also part of the state's nationalist propaganda.

The capitalism and globalisation category deserves a special attention due to its transcendence in the test. Here, the words such as troika (which appears 8 times), colonialism (6) and capitalism (4) (see Table 4) are included. It seems that students

In the former Soviet Union, troika was a politicaladministrative team made up of the President of the Republic, the Head of the State and the secretary General of the Communist Party. Nowadays, the word troika is frequently used in the media to refer to a power group from the European Commission, the European Central Bank and the International Monetary Fund. generally disapprove of the ways of doing politics in Europe. In the recent years troika has had a negative impact on the European population's collective thinking. European citizens see troika as adjustments, welfare cutbacks and scarcely supportive economic policies. It is where one of the inflection points in the European Union might be, severing itself from prior concepts of social commitment and good intentions (Macía et al. 2015).

However, the test results make no mention of the financial crisis, welfare cutbacks in health and education, the gradual disappearance of the welfare state, illegal immigration or xenophobia. In general, a more critical attitude towards political, social and economic realities in Europe is missing (Macía, Armas 2014). It is not feasible that the Greek crisis, the massive entrance of illegal immigrants, or the rise of fascist nationalist parties go unnoticed in the collective thinking of students in training to be secondary school teachers. In fact, it seems that, in curricular terms, the local reality is more important than European realities and the work of the supranational institutions is only of interest in terms of its capacity to influence the local population's quality of life. Therefore, a more reflective European geographical education is required, one that is critical of the current reality (Baylina, Prats 2002). At this moment, the geography curriculum adopts descriptive and rote learning approaches which do nothing towards building a fairer, unified society. Teaching and learning geography cannot be limited to a mere exercise of transmission and acquisition of scientific knowledge (Marrón 2011).

The prompted responses are only tenuously connected to the history of Europe. Students only associate the European continent with world wars, although it is also true that they generically 
Table 5. Categories shaping the semantic field on historical and cultural realities and interpretations after an associated word test on students in training to be teachers in secondary education.

\begin{tabular}{|l|r|r|r|r|r|r|}
\hline \multicolumn{1}{|c|}{ Associated words } & P1 & \multicolumn{1}{c|}{ P2 } & P3 & V1 & \multicolumn{1}{c|}{ V2 } & V3 \\
\hline History & 13 & 25 & 5.88 & 70 & 24.65 & 5.8 \\
\hline Cultural diversity & 10 & 19.23 & 4.52 & 76 & 26.76 & 6.3 \\
\hline Identity and heritage & 7 & 13.46 & 3.17 & 50 & 17.61 & 4.15 \\
\hline Culture & 6 & 11.54 & 2.71 & 39 & 13.73 & 3.23 \\
\hline Religion & 5 & 9.62 & 2.26 & 20 & 7.04 & 1.66 \\
\hline Education & 5 & 9.62 & 2.26 & 13 & 4.58 & 1.08 \\
\hline Art & 3 & 5.77 & 1.36 & 13 & 4.58 & 1.08 \\
\hline Music and sports & 3 & 5.77 & 1.36 & 3 & 1.06 & 0.25 \\
\hline Total values & 52 & 100 & 23.53 & 284 & 100 & 23.55 \\
\hline
\end{tabular}

Source: associated word pre-test on Europe, University of Santiago de Compostela, 2015.

refer to Classical Culture, Empires, the Middle Age and Enlightenment. They do not establish any relationship with some of the most important events in the history of Europe, such as the French Revolution, the Industrial Revolution, the Russian Revolution, the Cold War, the signing of the Treaty of Rome or the fall of communism.

However, for us, learning geography is of little use without any historical connection. The evolution of European political maps, with all the economic and social connotations, is the response to historical changes and strengthened borders. If history is not included then the task of trying to understand these territorial transformations is an impossible and impractical one and deprived of any teaching discipline (Villanueva 2004).

Finally, the identification of Europe and its people in terms as distinguished as heritage and identity is very positive (see Table 5). It is precisely in cultural and linguistic diversity that Europe finds its strength (Hernández 2000) and this concept seems to be present in a significant number of students $(23.48 \%)$. This is not a minor matter. In fact, during the 19th and 20th centuries, European nations promoted the cultural standardisation of various social groups within its borders (Rodríguez Lestegás 2009). To achieve these objectives, an educational system was planned to target "a single language, a single religion, a single law, a single nation and a single way of understanding history" (Valls 2002: 25).

\section{Conclusions}

The results of our research using an associated word test on Europe has provided a series of ideas and reflections connected to the perception of geographical realities on the continent and they could lead to changes in future teaching methods. Nevertheless, the research was conducted on a very small sample of university students training to be geography teachers in secondary school education and, therefore, the article does not have any intentions of extrapolating or generalising data or conclusions. In other words, the following ideas are only intended to spark debate on the teaching geography model in schools on our continent. Moreover, this article offers us an opportunity to say that it would be very interesting to carry on parallel research in other Spanish regions and the rest of Europe.

The following reflections are considered to be the most relevant:

1. A clear identification with immediate spaces is not noticeable. Thus, for a group of students from the northwest of Spain, the Mediterranean Sea is more important than the Atlantic Ocean in their spatial representations.

2. There seems to be a clear tendency to reduce Europe to the European Union. In social representations, students identify all constructed urban space with the European Union.

3. Peripheral areas remain on the fringe of spatial representations. Immediate associations are those of central Europe. Peripheral spaces have no place in collective thinking.

4. Nationalism and territorial tensions are not considered. European identity requires understanding of unique places and their interactions with other spaces. However, the test results show that nationalism is not part of the students' social representations. 
5. There is not a critical attitude towards the social and economic crisis. In general, there is a lack of a reflective and critical attitude towards the political, social and economic realities in Europe.

6. Major historical events on the continent are not reflected. Students omit some of the most important events in European history.

It is clear that the results of our small sample show that students learning to be geography teachers in secondary schools need a didactic training that is much more analytical, critical and reflective than the current one. This exercise has also shown that it is essential to work on the students' initial conceptions of European territory before introducing any theoretical session or practical work concerning European geography in the classroom.

\section{References}

Bale J., 2014. Geography in the primary school. Routledge, New York.

Baylina M., Prats M., 2002. Enseñar Europa. Un estímulo para la renovación de la geografía regional. Boletín de la A.G.E. 33: 51-64.

Bruno D., Barreiro A., Kriger M., 2011. Representaciones sociales de la política en los jóvenes: corrupción institucional y mentira. Kairos 28: 1-16.

Buzai G.D., 2011. La construcción de mapas mentales mediante apoyo geoinformático. Desde las imágenes perceptivas hacia la modelización digital. Revista Geográfica de Valparaíso 44: 1-17.

Claudino S., 2010. Portugal en los libros de texto españoles de geografía. In: Marrón Gaite M.J., De Lázaro y Torres M.L. (eds), Geografía, Educación y Formación del Profesorado en el Marco del Espacio Europeo de Educación Superior 1: 175-189. Murcia: Grupo de Didáctica de la Geografía, Asociación de Geógrafos Españoles.

DECRETO 86/2015, do 25 de xuño, polo que se establece o currículo da educación secundaria obrigatoria e do bacharelato na Comunidade Autónoma de Galicia. Diario Oficial de Galicia núm. 120 (29 de xuño de 2015).

DECRETO 133/2007, de 5 de xullo, polo que se regulan as ensinanzas da educación secundaria obrigatoria na Comunidade Autónoma de Galicia. Diario Oficial de Galicia núm. 136 (13 de xullo de 2007).

Denegri Coria M., Cabezas Gaete D., Sepúlveda Aravena J., del Valle Rojas C., González Gómez Y., Vargas H.M., 2010. Representaciones sociales sobre pobreza en estudiantes universitarios chilenos. Liberabit 16 (2): 161-170.

Elliott H.M., 1979. Mental maps and ethnocentrism: Geographic characterizations in the past. Journal of Geography 78 (7): 250-265.

EUROSTAT (2015). Statistics on European cities, Urban Audit. http://ec.europa.eu/eurostat/statistics-explained/ index.php/Statistics_on_European_cities
Ferrás Sexto C., 1996. Cambio rural na Europa Atlántica. Os casos de Irlanda e Galicia (1970-1990). Santiago de Compostela: Xunta de Galicia.

Gould P., White R., 1986. Mental maps. Routledge, London.

Gould P., 1972. On mental maps. In: English P.W., Mayfield R.C. (eds), Man, space and environment: Concepts in contemporary human geography. Oxford University, Oxford: 260-282.

Gil Saura E., 1994. Un ejemplo de uso de la asociación de palabras como técnica de recogida de datos sobre la representación del mundo social: la reconstrucción del campo semántico de los alumnos acerca del tema del Tercer Mundo. Didáctica de las Ciencias Experimentales y Sociales 8: $27-51$.

Hernández F.X., 2000. La enseñanza de las Ciencias Sociales en el nuevo contexto político europeo. ÍBER Didáctica de las Ciencias Sociales, Geografía e Historia 23: 7-16.

Liu J., Goldstein-Hawes R., Hilton D., Huang L.-L., Gastardo-Conaco C., Dresler-Hawke E., Pittolo F., Hong Y.-Y., Ward C., Abraham S., Kashima Y., Kashima E., Ohashi M.M., Yuki M., Hidaka Y., 2005. Social representations of events and people in world history across 12 cultures. Journal of Cross-Cultural Psychology 36 (2): 1-21.

Lois González R., Piñeira Mantiñán M.J., Santomil Mosquera D., 2009. Imagen y oferta de alojamiento en el medio rural de Galicia. Revista Galega de Economía 18 (2): 1-20.

Macía Arce X.C., Armas Castro X., 2015. Concepciones iniciales sobre Europa en un curso universitario de formación de maestros/as en educación primaria. Un estudio de caso fundamentado en la asociación de palabras. In: Hernández Carretero A.M., García Ruíz C.R., De la Montaña Conchiña J.L. (eds), Una enseñanza de las ciencias sociales para el futuro: recursos para trabajar la invisibilidad de personas, lugares y temáticas. Asociación Universitaria del Profesorado de Didáctica de las Ciencias Sociales, Cáceres: 871-880.

Macía Arce X.C., Rodríguez Lestegás F., Armas Quintá F.X., 2015. Manual de Aprendizaxe e Ensinanza de Xeografía e Ciencias Sociais para Educación Secundaria. Andavira, Santiago de Compostela.

Macía Arce X.C., Armas Quintá F.X., 2014. La construcción de la geografía escolar sobre Europa en las aulas de educación primaria. In: Vieira A., Julião R.P. (eds), XIV Colóquio Ibérico de Geografia: A jangada de pedra. Associação Portuguesa de Geógrafos and Departamento de Geografia da Universidade do Minho, Guimaraes 1: 65-70.

Macía Arce X.C., 2007. Sociedad de la Información en la Europa Atlántica. Análisis de casos en Galicia e Irlanda (ca. 19902000). Universidade de Santiago de Compostela, Santiago de Compostela.

Marrón Gaite M.J., 2011. Educación geográfica y formación del profesorado. Desafíos y perspectivas en el nuevo Espacio Europeo de Educación Superior (EEES). Boletín de la A.G.E. 57: 313-341.

NACIONES UNIDAS 1987. Our common future. Report of the word commission on environment and development. http:// www.un-documents.net/our-common-future.pdf

Novales Blanco X., Macía Arce X.C., 2017. Aproximación ás concepcións sobre Europa e a Unión Europea en educación secundaria: un estudo de caso con alumnado de Vilagarcía de Arousa. In: Macía Arce X.C. et al. (eds), Ensinar na Sociedade Actual. Andavira, Santiago de Compostela.

O’Flanagan P., 2001. Galicia en el marco geográfico e histórico de la Europa Atlántica. Xeográfica 1: 115-133. 
Prats J. (Dir.), Trepat C. (Coord.), Peña J.V., Valls R., Urgell F., 2001. Los jóvenes ante el reto europeo. Colección Estudios Sociales 7. Fundación La Caixa, Barcelona.

Rodríguez Fernández M., Macía Arce X.C., Rodríguez Lestegás F., 2017. Espazos naturais e formas do relevo en Europa: reflexións sobre unha experiencia de aula con estudantes de $1^{\circ}$ da ESO. In: Macía Arce X.C. et al. (eds), Ensinar na Sociedade Actual. Andavira, Santiago de Compostela.

Rodríguez Lestegás F., 2009. Educar geográficamente, educar cívicamente: la necesidad de construir una identidad europea intercultural. Didáctica Geográfica 10: 181-205.

Santos Solla X.M., 2015. Reflejos territoriales en destinos religiosos y de sol y playa. De Fátima a Benidorm. Investigaciones turísticas 9: 184-203.

Souto González X.M., 2013. Investigación e innovación educativa: el caso de la geografía escolar. Scripta Nova, XVII, (459), 1-42. http://www.ub.edu/geocrit/sn/sn-459. htm.
Storm M., 1984. Teaching about minorities. In: Fyson N. (ed.), The development puzzle. Hodder \& Stoughton, Sevenoaks. Universidade de Santiago de Compostela 2015. Pre-Test de Palabras Asociadas sobre Europa con alumnos del Máster Universitario en Profesorado de Educación Secundaria Obligatoria y Bachillerato, Formación Profesional y Enseñanzas de Idiomas.

Universidade de Santiago de Compostela 2014. Post-Test de Palabras Asociadas sobre Europa con alumnos del Grado para Maestros de Educación Primaria.

Valls Montés R., 2002. La dimensión europea en la enseñanza: orígenes y significados. In: Valls Montés R., López Serrano A. (eds), Dimensión europea e intercultural en la enseñanza de las ciencias sociales. Síntesis, Madrid: 19-40.

Villanueva M., 2004. Fronteras, identidades y diversidad: un ejercicio de "re-lectura" del mapa político de Europa. Enseñanza de las Ciencias Sociales 3: 103-108. 